\title{
SnAP reagents for the synthesis of piperazines and morpholines
}

\section{Journal Article}

\section{Author(s):}

Luescher, Michael U.; Vo, Cam-Van T.; Bode, Jeffrey W.

Publication date:

2014-02-21

Permanent link:

https://doi.org/10.3929/ethz-b-000260433

Rights / license:

In Copyright - Non-Commercial Use Permitted

Originally published in:

Organic Letters 16(4), https://doi.org/10.1021/ol500210z 


\title{
SnAP Reagents for the Synthesis of Piperazines and Morpholines
}

\author{
Michael U. Luescher, Cam-Van T. Vo, and Jeffrey W. Bode* \\ Laboratorium für Organische Chemie, ETH Zürich, CH-8093 Zürich, Switzerland \\ Supporting Information Placeholder
}

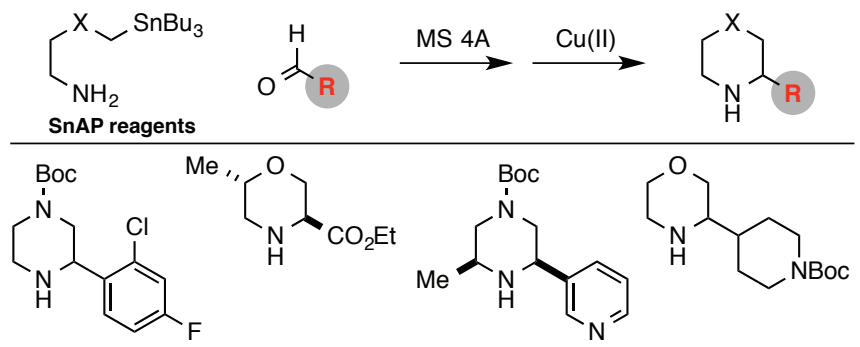

ABSTRACT: Substituted piperazines and morpholines are valuable structural motifs in biologically active compounds, but are not easily prepared by contemporary cross-coupling approaches. In this report, we introduce SnAP reagents for the transformation of aldehydes into $\mathrm{N}$-unprotected piperazines and morpholines. This approach offers simple, mild conditions compatible with aromatic, heteroaromatic, aliphatic, and glyoxylic aldehydes and provides mono- and disubstituted N-heterocycles in a single step.

We have recently introduced $\mathrm{SnAP}^{1}$ reagents for the simple synthesis of saturated N-heterocycles including thiomorpholines $^{2}$ and medium-sized rings. ${ }^{3}$ This process allows widely available aliphatic, aromatic, and heteroaromatic aldehydes to be converted to various N-heterocycles by a simple, general reaction protocol. It affords directly $N$-unprotected products, has outstanding substrate scope and functional group tolerance, and offers an easily recognized retrosynthetic disconnection. Mechanistically, we current favor a $\mathrm{Cu}^{\mathrm{II}}$-promoted generation of a stabilized radical that undergoes endo cyclization with the intermediate imine. We envision that readily prepared SnAP reagents and their equivalents will become commercially available building blocks for direct incorporation of saturated N-heterocycles via aldehyde synthetic handles (Figure 1).

In this report, we document SnAP reagents 1-6 for the synthesis of substituted, $\mathrm{N}$-unprotected piperazines and morpholines (Figure 2). We also introduce Me-substituted SnAP reagents for the diastereoselective synthesis of disubstituted morpholines and piperazines.

SnAP reagents 1-6 were prepared on a multigram scale by straightforward and efficient routes (see Supporting Information for full synthetic details). The SnAP reagents are easily handled, air- and moisture-stable liquids that can be stored for several weeks without decomposition. ${ }^{4}$ For the purposes of evaluation, a single reaction protocol was used in all of the cyclization reactions.

Piperazines prepared with SnAP Pip 1 were obtained in good yield using electron-poor and electron-rich aromatic, heteroaromatic and aliphatic aldehydes (Table 1). Sterically demanding 2-chloro-4-fluorobenzaldehyde (7b) and pivaldehyde (7f) afforded the 6-endo products in good yield.

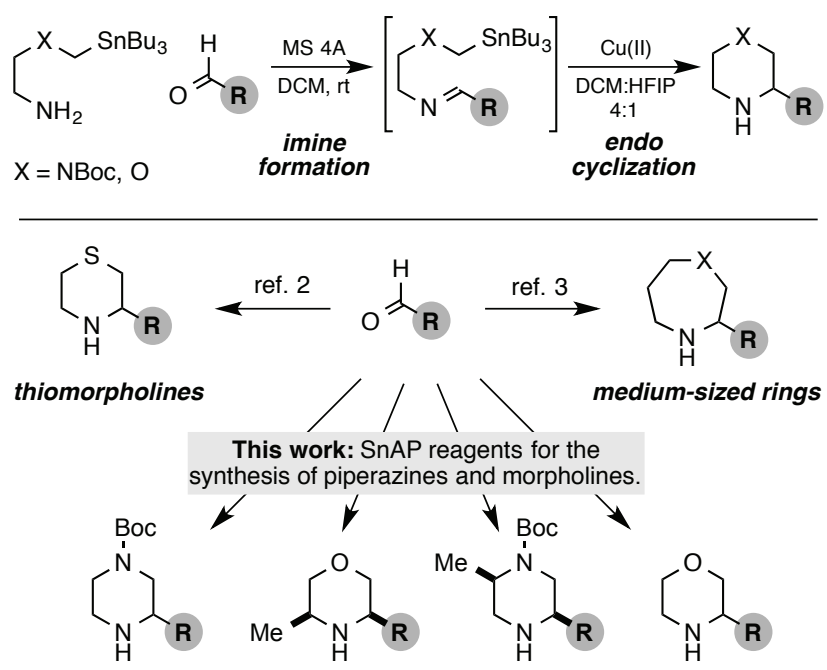

Figure 1. SnAP reagents for the synthesis of N-heterocycles from aldehydes.

Products containing groups suitable for further elaboration, including esters, organohalides and a variety of heterocycles, were easily prepared. Additionally, we were pleased to dis-

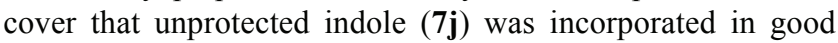
yield. Piperazines from unbranched aliphatic aldehydes were observed in lower yields, presumably due to the facile enamine formation. The major side products observed in the cyclization reactions were the protodestannylated imines. 


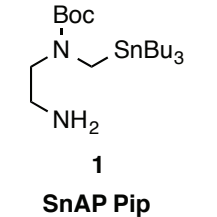

SnAP Piperazine 3 Steps $(61 \%)^{a}$

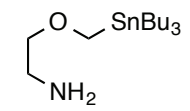

4

SnAP M SnAP Morpholine 4 Steps $(58 \%)^{a}$

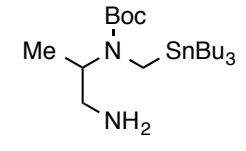

2

SnAP 2Me-Pip

SnAP 2-Methylpiperazine 5 Steps $(57 \%)^{a}$

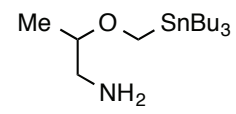

5

SnAP 2Me-M

$\begin{array}{cc}\text { SnAP 2-Methylmorpholine } & \text { SnAP 3-Methylmorpholine } \\ 3 \text { Steps }(80 \%)^{a} & 1 \text { Step }(87 \%)^{a}\end{array}$

Figure 2. SnAP reagents. ${ }^{a}$ Overall yield from commercially available starting materials.

Table 1. Piperazine synthesis with SnAP Pip $1^{a}$

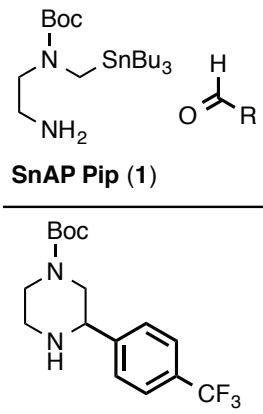

$7 a, 74 \% \pm 4 \%(n=3)$<smiles>CC(C)(C)OC(=O)N1CCNC(c2ccc3c(c2)OCO3)C1</smiles>

7d, $68 \%$

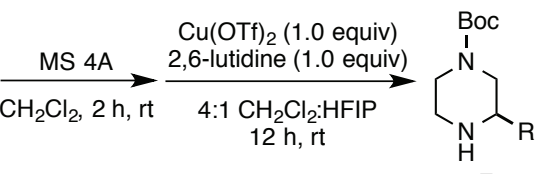

7

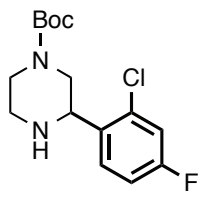

$7 b, 82 \%$

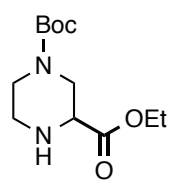

7 e, $75 \%$

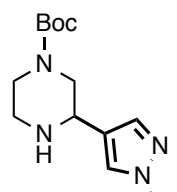

7i, $71 \% \mathrm{Me}$

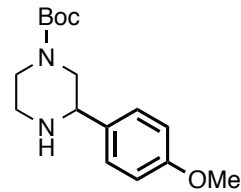

7c, $73 \% \pm 3 \%(n=2)$

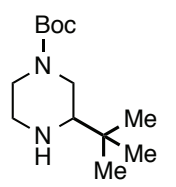

7f, $65 \%$<smiles>CC(C)(C)OC(=O)N1CCNC(C2CC2)C1</smiles>

7g, $75 \%$<smiles>CC(C)(C)OC(=O)N1CCNC(c2ccoc2)C1</smiles>

7h, $64 \%$

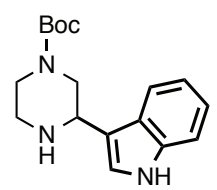

7j, $58 \%$
${ }^{a}$ Conditions: SnAP Pip 1 (1.0 equiv, $\left.0.5 \mathrm{mmol}\right)$, aldehyde $(1.0$ equiv, $0.5 \mathrm{mmol})$, MS 4A, $\mathrm{CH}_{2} \mathrm{Cl}_{2}(0.2 \mathrm{M}), 2 \mathrm{~h}$, rt; $\mathrm{Cu}(\mathrm{OTf})_{2}(1.0$ equiv, $0.5 \mathrm{mmol})$, 2,6-lutidine (1.0 equiv, $0.5 \mathrm{mmol}), 4: 1$ $\mathrm{CH}_{2} \mathrm{Cl}_{2}$ :HFIP $(0.05 \mathrm{M}), 12 \mathrm{~h}$, rt; isolated yield.

The synthesis of morpholines using SnAP M 4 showed again a broad substrate scope, functional group tolerance, and afforded the desired $N$-unprotected heterocycles in good to excellent yields from electron-poor and electron-rich aromatic, heteroaromatic and aliphatic aldehydes (Table 2). The reaction with bulky 2,4,6-mesitylaldehyde (8d) was slow, promoting the formation of destannylated side product. Elevated temperature did not improve the overall yield; only traces of the desired product were observed. As reported for the synthesis of the thiomorpholines, ${ }^{2}$ 2-pyridinylaldehyde $(\mathbf{8 k})$, which can chelate the $\mathrm{Cu}^{\mathrm{II}}$, also showed poor reactivity and the starting material was recovered.
Table 2. Morpholine synthesis with $\operatorname{SnAP} M 4^{a}$

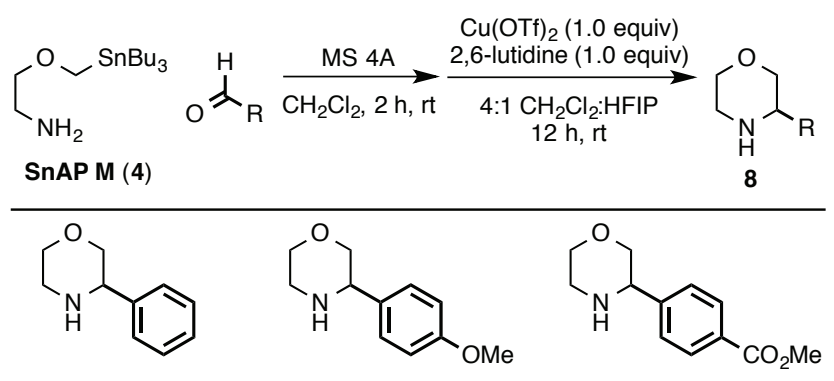

8 a, $68 \%$

8b, $94 \%$

8c, $79 \%$<smiles>Cc1cc(C)c(C2COCCN2)c(C)c1</smiles>

8d, $<5 \%{ }^{b}$<smiles>Brc1cccc(C2COCCN2)c1</smiles>

8 e, $66 \%$<smiles>CCOC(=O)C1COCCN1</smiles>

8f, $84 \%$

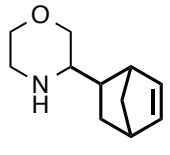

$8 g, 68 \%{ }^{c}$<smiles></smiles>

8h, $60 \%$<smiles>c1ccc2c(C3COCCN3)csc2c1</smiles>

8i, $85 \%$<smiles>c1cc(C2COCCN2)ccn1</smiles>

8j, $79 \%$

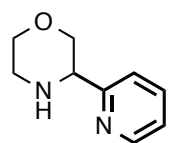

$8 k,<10 \% b$
${ }^{a}$ Conditions: SnAP M 4 (1.0 equiv, $\left.0.5 \mathrm{mmol}\right)$, aldehyde (1.0 equiv, $0.5 \mathrm{mmol}), \mathrm{MS} 4 \mathrm{~A}, \mathrm{CH}_{2} \mathrm{Cl}_{2}(0.2 \mathrm{M}), 2 \mathrm{~h}, \mathrm{rt} ; \mathrm{Cu}(\mathrm{OTf})_{2}(1.0$ equiv, $0.5 \mathrm{mmol})$, 2,6-lutidine (1.0 equiv, $0.5 \mathrm{mmol}), 4: 1$ $\mathrm{CH}_{2} \mathrm{Cl}_{2}$ :HFIP $(0.05 \mathrm{M}), 12 \mathrm{~h}$, rt; isolated yield. ${ }^{b} 4: 1$ DCE:HFIP, $12 \mathrm{~h}, 60{ }^{\circ} \mathrm{C}$; yield determined by ${ }^{1} \mathrm{H}$ NMR with $1,3,5-$ trimethoxybenzene as internal standard. ${ }^{c}$ As a mixture of diastereomers.

In general, the formation of the piperazines and morpholines proved more efficient for a broad range of aldehydes and occurred in overall higher yields compared to the thiomorpholine ${ }^{2}$ synthesis. $\mathrm{CaSO}_{4}$, which we employed in the thiomorpholine synthesis as drying agent, can be left out without deterioration of product formation. We anticipated that substrate specific optimization will be possible if higher yields or faster reaction times are necessary. ${ }^{5}$ An advantage of this protocol for the preparation of diverse $\mathrm{N}$-heterocycles is the simple reaction setup: the SnAP reagent is combined with the aldehyde in the presence of molecular sieves to afford the corresponding imine, which is cyclized with stoichiometric $\mathrm{Cu}(\mathrm{OTf})_{2}$ and 2,6-lutidine in 4:1 $\mathrm{CH}_{2} \mathrm{Cl}_{2}$ :HFIP at rt for $12 \mathrm{~h}$. The imines were processed by filtration over a glass sintered funnel and evaporated to ensure clean and full conversion before subjection to the cyclization. Alternatively, the imine formation can be diluted with additional $\mathrm{CH}_{2} \mathrm{Cl}_{2}$ and transferred to the heterogeneous copper/ligand suspension by a syringe equipped with an HPLC filter.

The introduction of additional substituents into the targeted piperazine or morpholine can dramatically complicate their synthesis by traditional methods. To examine the feasibility of our approach for the facile diastereoselective synthesis of disubstituted morpholines and piperazines, we prepared methyl substituted SnAP reagents 2-3 and 5-6 via short reaction sequences. Cyclization under standard conditions afforded the representative disubstituted $N$-unprotected saturated heterocycles in moderate to good yields with the usual broad substrate scope (Table 3). 
Table 3. Synthesis of disubstituted piperazines and morpholines with SnAP reagents ${ }^{a, b, c}$

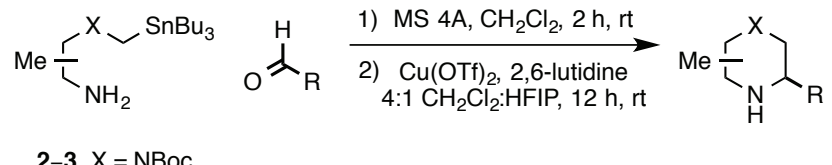

$$
\begin{aligned}
& \text { 2-3, } X=\text { NBoc } \\
& 5-6, X=O
\end{aligned}
$$<smiles>CCOC(=O)C1CN(C(=O)OCc2ccccc2)C(C)CN1</smiles><smiles>Cc1ccccc1[C@@H]1CN(C(=O)OC(C)(C)C)[C@@H](C)CN1</smiles>

$9 b, 63 \%{ }^{d}$

$9 a, 61 \%^{d}$ d.r. $=3: 2$<smiles>CCOC(=O)[C@@H]1CN(C(=O)OC(C)(C)C)C[C@H](C)N1</smiles><smiles>C[C@H]1CN(C(=O)OC(C)(C)C)C[C@H](c2cccnc2)N1</smiles>

$$
10 \mathrm{~b}, 86 \%
$$
d.r. $>10: 1$ d.r. $>10: 1$

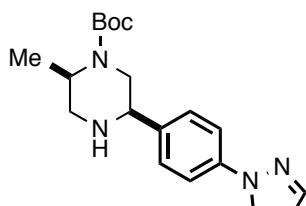

$9 c, 75 \%{ }^{d}$ d.r. $=8: 3$

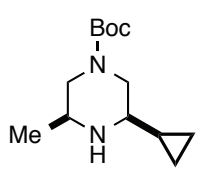

10c, $79 \% e$<smiles>CCOC(=O)[C@@H]1CO[C@@H](C)CN1</smiles>

11a, $79 \%^{e}$ d.r. $>10: 1$<smiles>CCOC(=O)[C@@H]1COC[C@@H](C)N1</smiles>

12a, $51 \%^{e}$ d.r. $\geq 5: 1$

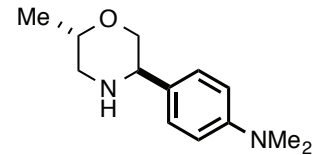

11b, $43 \%^{e}$ d.r. $\geq 5: 1$

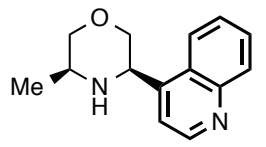

12b, $80 \% \pm 4 \%{ }^{e, f}(n=2)$
${ }^{a}$ Conditions: SnAP reagent $\mathbf{2 - 3}, \mathbf{5}-\mathbf{6}$ (1.0 equiv, $\left.0.5 \mathrm{mmol}\right)$, aldehyde (1.0 equiv, $0.5 \mathrm{mmol})$, MS $4 \mathrm{~A}, \mathrm{CH}_{2} \mathrm{Cl}_{2}(0.2 \mathrm{M}), 2 \mathrm{~h}$, rt; $\mathrm{Cu}(\mathrm{OTf})_{2}$ (1.0 equiv, $\left.0.5 \mathrm{mmol}\right)$, 2,6-lutidine (1.0 equiv, 0.5 $\mathrm{mmol}), 4: 1 \mathrm{CH}_{2} \mathrm{Cl}_{2}$ :HFIP $(0.05 \mathrm{M}), 12 \mathrm{~h}$, rt; isolated yield. ${ }^{b}$ Diastereomeric ratio was determined by ${ }^{1} \mathrm{H}$ NMR spectroscopy of the unpurified reaction mixtures. ${ }^{c}$ Relative stereochemistry was confirmed by X-ray analysis of $( \pm)-\mathbf{9 b}$ and $( \pm)-\mathbf{1 1 b}$; others assigned by analogy and NOESY spectroscopy. ${ }^{d}$ Yield of major and minor diastereomers combined. ${ }^{e}$ Yield of major diastereomer. ${ }^{f}$ Enantioenriched $(S)$-SnAP 3Me-M 6 (ee > 98\%) was used.

The diastereomeric ratio varied depending on the SnAP reagents used. 3,5-disubstituted piperazines $(\mathbf{1 0 a}-\mathbf{c})$ and morpholines (12a-b) bearing substituents in 1,3-relationship generally showed a high diastereomeric ratio towards the thermodynamically favored isomer. SnAP 2Me-M 5 gave predominantly trans-configured 3,6-disubstituted morpholines (11a-b) (Figure 3a) and SnAP 2Me-Pip 2 afforded the 1,4diazacyclohexanes $(\mathbf{9 a}-\mathbf{9 c})$ as a mixture of separable diastereomers, favoring the cis-isomers (Figure 3b). We attribute the reduced diastereoselectivity with SnAP 2Me-Pip 2 to the presence of the $N$-tert-butoxycarbonyl group next to the methyl, which is forced into the axial position to reduce steric interactions. No racemization during the synthesis of $\mathbf{1 2} \mathbf{b}$ was detected using enantiomerically pure SnAP $3 \mathrm{Me}-\mathrm{M} \mathrm{6}{ }^{6}{ }^{6}$ permitting fast access to enantiomerically pure bulding blocks. ${ }^{7}$

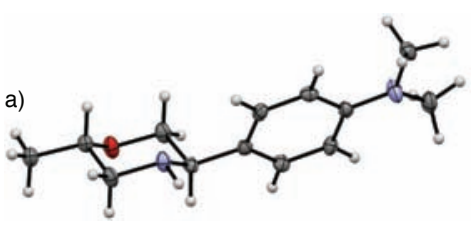

$( \pm)-11 b$

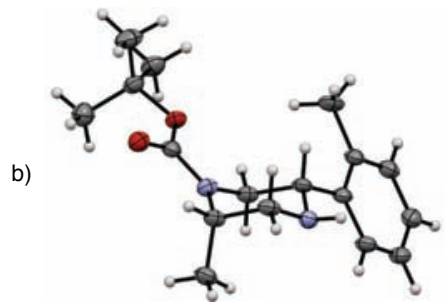

$( \pm)-9 b$
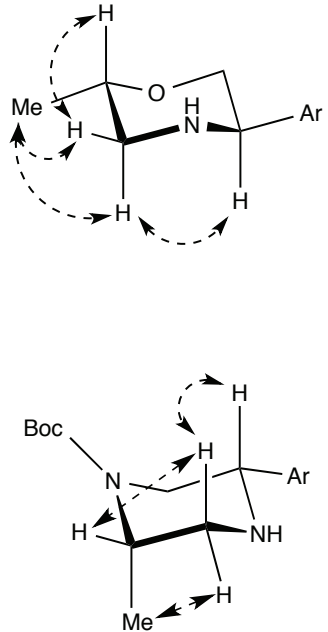

Figure 3. X-ray structure of $( \pm)-\mathbf{1 1 b}$ and $( \pm)-\mathbf{9 b}$ and stereochemical assignment by NOESY spectroscopy.

Piperazines and morpholines are important elements in natural products and small bioactive molecules. ${ }^{8}$ Despite the importance of these building blocks, their applications in medicinal chemistry are challenging due to poor commercial availability and the often-laborious synthetic routes that rely on ring closure $^{9}$ or $\alpha$-functionalization. ${ }^{10}$ Successful approaches using vinyl sulfonium salts, ${ }^{11}$ vinyl selenones, ${ }^{12}$ epoxides,${ }^{13}$ aziridines,${ }^{14}$ or glyoxal derivatives ${ }^{15}$ require rather advanced precursors, making the preparation of diverse substitution patterns or heterocycle types laborius. These new SnAP reagents should therefore fulfill a need for the rapid preparation of morpholines and piperazines not currently met by existing methods. We also anticipate that the reagent design and reactions can easily be adapted to accommodate SnAP reagents with additional substituents and functional groups.

In summary, we have developed new SnAP reagents for the synthesis mono- and disubstituted piperazines and morpholines. The cyclization takes place under mild conditions at room temperature and affords the $N$-unprotected, saturated $\mathrm{N}$ heterocycles in good to excellent yields. This methodology accepts a wide range of electronically and sterically diverse aromatic, heteroaromatic, glyoxylic, and aliphatic aldehydes bearing variety of functional groups including esters, protected amines, organohalides, ethers, and various heterocycles were tolerated.

\section{ASSOCIATED CONTENT}

\section{Supporting Information}

Experimental procedures, characterizations, spectral data for all new compounds, and the data for single-crystal X-ray diffraction of compounds $( \pm)-\mathbf{9 b}$ and $( \pm)-\mathbf{1 1 b}(\mathrm{CIF})$. This material is available free of charge via the Internet at http://pubs.acs.org.

\section{AUTHOR INFORMATION}

\section{Corresponding Author}

*Email: bode@org.chem.ethz.ch 


\section{Author Contributions}

M.U.L. and C. V. V. performed the experiments, compound characterization and data analysis. All authors contributed in experiment design and discussions.

\section{Notes}

The authors declare no competing financial interest.

\section{ACKNOWLEDGMENT}

This work was supported by an ETH Research Grant (ETH-12 111) and the European Research Council (ERC Starting Grant No. 306793 - CASAA). The authors acknowledge the LOC Mass Spectrometry Service, the LOC NMR Service, and the Small Molecule Crystallography Center of ETH Zurich for the X-ray measurement.

\section{REFERENCES}

(1) $\mathrm{SnAP}=\operatorname{tin}(\mathrm{Sn})$ Amine Protocol

(2) Vo, C.-V. T.; Mikutis, G.; Bode, J. W. Angew. Chem. Int. Ed. 2013, 52, 1705-1708.

(3) Vo, C.-V. T.; Luescher, M. U.; Bode, J. W. Nat. Chem. in press.

(4) SnAP reagents are usually stored neat at $-10{ }^{\circ} \mathrm{C}$ for months without detectable decompositions.

(5) The formation of $\mathbf{8 c}$, for example, is completed after $2 \mathrm{~h}$ at rt; all reactions are completed after $12 \mathrm{~h}$ at $\mathrm{rt}$.

(6) Enantiomerically pure SnAP 3Me-M 6 was synthesized in onestep from enantiomerically pure $(S)-(+)$-2-amino-1-propanol without detectable racemization.

(7) See Supporting Infromation.

(8) (a) Bruncko, M.; Oost, T. K.; Belli, B. A.; Ding, H.; Joseph, M. K.; Kunzer, A.; Martineau, D.; McClellan, W. J.; Mitten, M.; Ng, S.C.; Nimmer, P. M.; Oltersdorf, R.; Park, C.-M.; Petros, A. M.; Shoemaker, A. R.; Song, X.; Wang, X.; Wendt, M. D.; Zhang, H.; Fesik, S. W.; Rosenberg, S. H.; Elmore, S. W. J. Med. Chem. 2007, 50, 641-
662. (b) Ward, S. E.; Harrington, F. P.; Gordon, L. J.; Hopley, S. C.; Scott, C. M.; Watson, J. M. J. Med. Chem. 2005, 48, 3478-3480. (c) Leopoldo, M.; Lacivita, E.; Colabufo, N. A.; Contino. M.; Berardi, F.; Perrone, R. J. Med. Chem. 2005, 48, 7919-7922. (d) Wijtmans, R.; Vink, M. K. S.; Schoemaker, H. E.; van Delft, F. L.; Blaauw, R. H.; Rutjes, F. P. J. T. Synthesis 2004, 641-662. For natural products, see: (e) Lin, C.; Huang, P.; Lu, C.; Wu, R.; Hu, W.; Wang, J. Tetrahedron 1997, 53, 2025-2028. (f) Fujita, T.; Hayashi, H. Biosci. Biotechnol. Biochem. 2004, 68, 820-826. (g) Kohmoto, S.; Kashman, Y.; McConnell, O. J., Jr.; Rinehart, K. L., Jr.; Wright, A.; Koehn, F. J. Org. Chem. 1988, 53, 3116-3118.

(9) For some recent examples, see: (a) Ruider, S. A.; Müller, S.; Carreira, E. M. Angew. Chem. Int. Ed. 2013, 52, 11908-11911. (b) Zhai, H.; Borzenko, A.; Lau, Y. Y.; Ahn, S. H.; Schafer, L. L. Angew. Chem. Int. Ed. 2012, 51, 12219-12223. (c) Lu, Z.; Stahl, S. S. Org. Lett. 2012, 14, 1234-1237. (d) Leathen, M. L.; Rosen, B. R.; Wolfe, J. P. J. Org. Chem. 2009, 74, 5107-5110. (e) Cochran, B. M.; Michael, F. E. Org. Lett. 2008, 10, 329-332. (f) Nakhla, J. S.; Wolfe, J. P. Org. Lett. 2007, 9, 3279-3282. (g) Lanman, B. A.; Myers, A. G. Org. Lett. 2004, 6, 1045-1047.

(10) For reviews, see: (a) Mitchell, E. A.; Peschiulli, A.; Lefevre, N.; Meerpoel, L.; Maes, B. U. W. Chem. Eur. J. 2012, 18, 10092 10142. (b) Campos, K. R. Chem. Soc. Rev. 2007, 36, 1069-1084.

(11) (a) Yar, M.; McGarrigle, E. M.; Aggarwal, V. K. Angew. Chem. Int. Ed. 2008, 47, 3784-3786. (b) Yar, M.; McGarrigle, E. M.; Aggarwal, V. K. Org. Lett. 2009, 11, 257-260. (c) Yar, M.; Fritz, S. P.; Gates, P. J.; McGarrigle, E. M.; Aggarwal, V. K. Eur. J. Org. Chem. 2012, 160-166.

(12) Bagnoli, L.; Scarponi, C.; Rossi, M. G.; Testaferri, L.; Tiecco, M. Chem. Eur. J. 2011, 17, 993-999.

(13) Breuning, M.; Winnacker, M.; Steiner, M. Eur. J. Org. Chem. 2007, 2100-2106.

(14) Wang, L.; Liu, Q.-B.; Wang, D.-S.; Li, X.; Han, X.-W.; Xiao, W.-J.; Zhou, Y.-G. Org. Lett. 2009, 11, 1119-1122.

(15) Berrée, F.; Debache, A.; Marsac, Y.; Carboni, B. Tetrahedron Lett. 2001, 42, 3591-3594. 


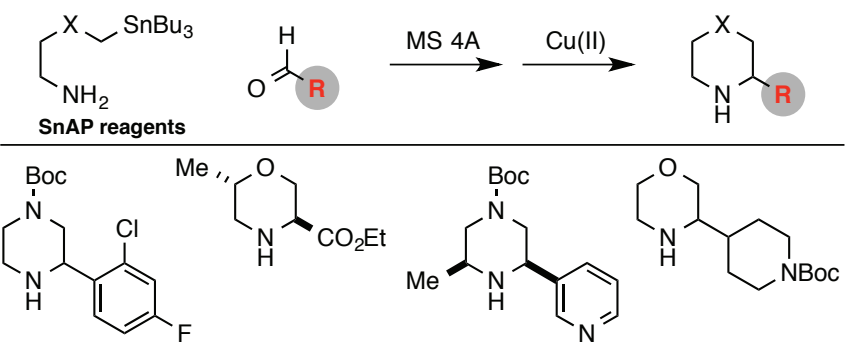


(1) $\mathrm{SnAP}=\operatorname{tin}(\mathrm{Sn})$ Amine Protocol

(2) Vo, C.-V. T.; Mikutis, G.; Bode, J. W. Angew. Chem. Int. Ed. 2013, 52, 1705-1708.

(3) Vo, C.-V. T.; Luescher, M. U.; Bode, J. W. Nat. Chem. in press.

(4) SnAP reagents are usually stored neat at $-10^{\circ} \mathrm{C}$ for months without detectable decompositions.

(5) The formation of $\mathbf{8 c}$, for example, is completed after $2 \mathrm{~h}$ at rt; all reactions are completed after $12 \mathrm{~h}$ at $\mathrm{rt}$.

(6) Enantiomerically pure SnAP 3Me-M 6 was synthesized in one-step from enantiomerically pure $(S)-(+)$-2-amino-1-propanol without detectable racemization.

(7) See Supporting Infromation.

(8) (a) Bruncko, M.; Oost, T. K.; Belli, B. A.; Ding, H.; Joseph, M. K.; Kunzer, A.; Martineau, D.; McClellan, W. J.; Mitten, M.; Ng, S.-C.; Nimmer, P. M.; Oltersdorf, R.; Park, C.-M.; Petros, A. M.; Shoemaker, A. R.; Song, X.; Wang, X.; Wendt, M. D.; Zhang, H.; Fesik, S. W.; Rosenberg, S. H.; Elmore, S. W. J. Med. Chem. 2007, 50, 641-662. (b) Ward, S. E.; Harrington, F. P.; Gordon, L. J.; Hopley, S. C.; Scott, C. M.; Watson, J. M. J. Med. Chem. 2005, 48, 3478-3480. (c) Leopoldo, M.; Lacivita, E.; Colabufo, N. A.; Contino. M.; Berardi, F.; Perrone, R. J. Med. Chem. 2005, 48, 7919-7922. (d) Wijtmans, R.; Vink, M. K. S.; Schoemaker, H. E.; van Delft, F. L.; Blaauw, R. H.; Rutjes, F. P. J. T. Synthesis 2004, 641-662. For natural products see: (e) Lin, C.; Huang, P.; Lu, C.; Wu, R.; Hu, W.; Wang, J. Tetrahedron 1997, 53, 2025-2028. (f) Fujita, T.; Hayashi, H. Biosci. Biotechnol. Biochem. 2004, 68, 820-826. (g) Kohmoto, S.; Kashman, Y.; McConnell, O. J., Jr.; Rinehart, K. L., Jr.; Wright, A.; Koehn, F. J. Org. Chem. 1988, 53, 3116-3118.

(9) For some recent examples see: (a) Ruider, S. A.; Müller, S.; Carreira, E. M. Angew. Chem. Int. Ed. 2013, 52, 11908-11911. (b) Zhai, H.; Borzenko, A.; Lau, Y. Y.; Ahn, S. H.; Schafer, L. L. Angew. Chem. Int. Ed. 2012, 51, 12219-12223. (c) Lu, Z.; Stahl, S. S. Org. Lett. 2012, 14, 1234-1237. (d) Leathen, M. L.; Rosen, B. R.; Wolfe, J. P. J. Org. Chem. 2009, 74, 5107-5110. (e) Cochran, B. M.; Michael, F. E. Org. Lett. 2008, 10, 329-332. (f) Nakhla, J. S.; Wolfe, J. P. Org. Lett. 2007, 9, 3279-3282. (g) Lanman, B. A.; Myers, A. G. Org. Lett. 2004, 6, $1045-1047$.

(10) For reviews see: (a) Mitchell, E. A.; Peschiulli, A.; Lefevre, N.; Meerpoel, L.; Maes, B. U. W. Chem. Eur. J. 2012, 18, 10092-10142. (b) Campos, K. R. Chem. Soc. Rev. 2007, 36, 1069-1084.

(11) (a) Yar, M.; McGarrigle, E. M.; Aggarwal, V. K. Angew. Chem. Int. Ed. 2008, 47, 3784-3786. (b) Yar, M.; McGarrigle, E. M.; Aggarwal, V. K. Org. Lett. 2009, 11, 257-260. (c) Yar, M.; Fritz, S. P.; Gates, P. J.; McGarrigle, E. M.; Aggarwal, V. K. Eur. J. Org. Chem. 2012 , $160-166$.

(12) Bagnoli, L.; Scarponi, C.; Rossi, M. G.; Testaferri, L.; Tiecco, M. Chem. Eur. J. 2011, 17, 993-999.

(13) Breuning, M.; Winnacker, M.; Steiner, M. Eur. J. Org. Chem. 2007, 2100-2106.

(14) Wang, L.; Liu, Q.-B.; Wang, D.-S.; Li, X.; Han, X.-W.; Xiao, W.-J.; Zhou, Y.-G. Org. Lett. 2009, 11, 1119-1122.

(15) Berrée, F.; Debache, A.; Marsac, Y.; Carboni, B. Tetrahedron Lett. 2001, 42, 3591-3594. 